\title{
The utilization of flour made of the non-milled rice as analog rice ingredients
}

\author{
${ }^{1 *}$ Sukamto, S. and ${ }^{2}$ Patria, D.G. \\ ${ }^{I}$ Department of Agricultural and Food Technology, Faculty of Agriculture, Widyagama University, Malang, \\ Indonesia \\ ${ }^{2}$ Department of Agricultural Product Technology, Faculty of Agriculture Technology, Brawijaya University, \\ Malang, Indonesia
}

\section{Article history: \\ Received: 12 March 2020 \\ Received in revised form: 9 April 2020 \\ Accepted: 14 April 2020 \\ Available Online: 29 April 2020}

\section{Keywords:}

Analog rice,

Formula,

Ingredient,

Milled rice

\section{DOI:}

https://doi.org/10.26656/fr.2017.4(5).108

\begin{abstract}
The continual increment of a population requires sufficient food, while agricultural land for rice cultivation keeps on declining. Therefore, the habit of consuming rice needs to be reduced. This study was aimed to get the best quality analog rice from non-milled rice based on the proportion of raw materials, time, and sensory. This study used the ingredients of cassava flour, sorghum, sweet potatoes, corn + lablab bean, and soybeans. Cooking oil, salt, glycerol monostearate, Na-alginate, and sodium three polyphosphates were used as additional ingredients and mixed in various formulation/ratios. These formula ingredients were extruded using KL Protecal Twin-screw to produce analog rice grains. A randomized block design was used in this study. The randomized block design was repeated three times. In order to determine the best treatment, this study employed the $5 \%$ LSD test. The results of this study showed that flour from cassava, sweet potato, sorghum, corn + lablab bean, and soybeans can be formulated as an analog rice ingredient. Cassava flour, sweet potato, sorghum, corn + lablab bean were used as the source of carbohydrates, and the soy flour was used as a source of protein. This study found that the best ratio would be 4.5: 4.5: 1 for cassava flour: $50 \%$ corn $+50 \%$ lablab bean flour: soy flour. The cooking process required $1.5 \mathrm{~mL}$ to $2 \mathrm{~mL}$ of water per gram of analog rice, and the cooking time would be $10-15$ mins. The sensory values of color, taste, aroma, and texture were on the scale of average like to very like.
\end{abstract}

\section{Introduction}

Uncontrolled food consumption patterns and population growth might lead us to the other 2 problems, namely: Development of population during the lack of food availability and over-consuming people resulting in overweight and obesity (Sukamto et al., 2019). On the other hand, the rate of paddy field conversion is relatively high. For example, the rate of paddy field conversion in Indonesia is $96,512 \mathrm{ha}^{-1}$. It is estimated that the provided rice field area of 8.1 million ha will be reduced to 5.1 million ha by 2045 (Mulyani et al., 2016). Degradation of land availability causes rice production to decline. The world food balance is also heading to an imbalance condition because the food demand is higher than the food production (Gandhi and Zhou, 2014; Fukase and Martin, 2017). Therefore, the habit of consuming rice needs to be balanced immediately with the consumption of non-rice materials such as analog rice because it is produced from non-rice raw material.
Analog rice is illustrated as a rice-shaped grain formulated from non-rice ingredients so that the human's energy and protein can be fulfilled (Sukamto, 2018). Analog rice can also be formulated specifically to provide the benefit of functional food for obese and overweight sufferers, diabetes mellitus, hypercholesterolemia, and others. Non-rice plants such as cassava, sorghum, corn, and sweet potato are the types of plants which can be used as the source of carbohydrates, and they are deemed perfect as the main ingredients in making analog rice. These plants can be cultivated more easily than rice plants. They are more tolerant of land conditions and they do not require much water. The use of soy flour in analog rice formula is intended to increase the amount of protein because soy protein has complete amino acids (Sukamto et al., 2019). Analog rice is usually made from one type of the main ingredient. For example, analog rice can be made from white corn (Noviasari et al., 2013), arrowroot flour (Caesarina and Estiasih, 2016), sweet potatoes (Hasnelly, 
and Putri, 2013) or White Greater Yam (Discorea alata L.) (Adicandra and Estiasih, 2016). The level of carbohydrates and nutrients of analog rice formulated from a single type of base material are relatively varied, making them the incomplete grain', and they might cause deficiency of some nutrients such as amino acids or other types of carbohydrates.

This research was carried out in order to produce analog rice that uses a combination of non-rice ingredients (sorghum, cassava, sweet potatoes, corn, lablab bean, and soybeans). The expected result of this research was the availability of a quality analog rice product that contains a relatively complete variety of nutrients so that, in the future, it can replace the role of milled rice as a staple food. This study aims to get the best quality analog rice from non-milled rice based on the proportion of raw materials, time, and sensory.

\section{Materials and methods}

\subsection{Materials}

The primary materials of this study consisted of cassava flour, sweet potato flour, corn + lablab bean flour, sorghum flour, and soy flour produced by local farmers of Malang, Indonesia. The food-grade additives were composed of salt, glycerol monostearate (GMS), Na.alginate and sodium three polyphosphates (STPP).

\subsection{Research methods}

The treatment groups in this research were the number of flour mixture formulas, including; Formula A (FA): a mixed flour from cassava $45 \%(4.5 \mathrm{~kg})$, sorghum $45 \%(4.5 \mathrm{~kg})$, and soybean $10 \%(1 \mathrm{~kg})$; Formula B (FB): a mixed flour from $45 \%(4.5 \mathrm{~kg})$ cassava, $45 \%$ (4.5 $\mathrm{kg})$ sweet potato, and $10 \%(1 \mathrm{~kg})$ soybean; and the Formula C (FC): a mixed flour from $45 \%(4.5 \mathrm{~kg})$ cassava, $45 \%(4.5 \mathrm{~kg})$ from $50 \%$ corn $+50 \%$ lablab bean, and $10 \%(1 \mathrm{~kg})$ soybean. $\mathrm{N}$ was the milled rice serving as the control group. The formula compositions used in this study will be explained in Table 1. The randomized block design was used in this study and it was repeated three times. In order to determine the best treatment, the 5\% LSD test was performed.

Table 1. The formula for the treatment of the main ingredients in analog rice

\begin{tabular}{lccc}
\hline Flours & $\begin{array}{c}\text { Formula A } \\
(\mathrm{kg})\end{array}$ & $\begin{array}{c}\text { Formula B } \\
(\mathrm{kg})\end{array}$ & $\begin{array}{c}\text { Formula C } \\
(\mathrm{kg})\end{array}$ \\
\hline Cassava & 4.5 & 4.5 & 4.5 \\
Sorghum & 4.5 & 0 & 0 \\
Sweet potato & 0 & 4.5 & 0 \\
50\% Corn $+50 \%$ lablab & 0 & 0 & 4.5 \\
Soybean & 1 & 1 & 1 \\
Total & 10 & 10 & 10 \\
\hline
\end{tabular}

Each of the $10 \mathrm{~kg}$ formulae was added with $250 \mathrm{~g}$ cooking oil, $50 \mathrm{~g}$ salt, $25 \mathrm{~g}$ glycerol monostearate (GMS), 25g Na.alginate, and $25 \mathrm{~g}$ sodium three polyphosphates (STPP). The extrusion of analog rice was performed using KL Protecal Twin-screw extruder possessed by CV. Wijaya Food, Blitar Regency, Indonesia. Each of the materials, which was $10 \mathrm{~kg}$ in weight (determined according to the treatment formula) were mixed using a dry mixer for 10 mins and they were combined with cooking oil, salt, glycerol monostearate, and Na.alginate and Sodium Three Poly Phosphate (STTP). They were added with moisture in the amount of $40 \%$ of the material weight. The temperature of the screw extruder at the beginning, middle, and end of the extruding process were $80^{\circ} \mathrm{C}, 85^{\circ} \mathrm{C}$, and $90^{\circ} \mathrm{C}$ respectively. The screw speed of the extruder was $40 \mathrm{~Hz}$, and the cutting speed was $20 \mathrm{~Hz}$. Analog rice grains coming out of the extruder were dried until the moisture content reduced to $10 \%$.

The proximate analysis of nutrition composition was applied to the protein, fat, starch, amylose, crude fiber, and ash content using the method of (AOAC, 1995).

Bulk density was calculated using the method of (Fang et al., 2019) with the following formula:

$$
\mathrm{BD}(\mathrm{g} / \mathrm{mL})=\frac{\mathrm{W} 2-\mathrm{W} 1}{\mathrm{~V}}
$$

Where W1 = Weight of beaker glass (g), W2 = Weight of analog rice and beaker glass $(\mathrm{g})$, and $\mathrm{V}=$ analog rice volume $\left(\mathrm{cm}^{3}\right)$

The cooking time was evaluated using a method employed by (Noviasari et al., 2013), but it was modified as follows: analog rice was cooked by using the rice cooker, water, and rice with the ratio of 1: 1.5. The water was cooked first in a rice cooker until it boils. Then, we put the analog rice in and cooked it until done. The cooking duration was calculated from the time when the analog rice entered the rice cooker.

The cooking weight was observed using a method of (Fari et al., 2011), but it was modified as follows: $2 \mathrm{~g}$ of analog rice was added with $3 \mathrm{~g}$ water. The analog rice was cooked in boiling water until done, rinsed with $20 \mathrm{~mL}$ distilled water and drained at room temperature for 2 mins. The cooking weight was determined by weighing the wet analog rice. The percentage of cooking weight was calculated by using the following equation:

$$
\text { Cooking weight }(\%)=\frac{\text { Weight of wet analogs }}{\text { Weight of dry analogs }} \times 100
$$

The Water Absorption Index (WAI) was observed using the method of (Katsavou et al., 2019) with the following formula: 


$$
W A I(\%)=\frac{W_{B}-W_{A}}{W_{A}} \times 100
$$

Where $\mathrm{W}_{\mathrm{A}}=$ Weight of the sample before immersion $(\mathrm{g})$ and $\mathrm{W}_{\mathrm{B}}=$ weight of sample after immersion $(\mathrm{g})$.

The percentages of rehydration and cooking loss were determined using the method employed by (Yogeshwari et al., 2018). Analog rice was cooked according to the cooking time. The analog rice that had been cooked was then washed with water and drained for 2 mins. Then the rice was taken and weighed to determine the rehydration percentage. The cooking water and washing water were collected in the Petri dish (the weight of the empty Petri dish is weighed before), and dried in an oven at $105^{\circ} \mathrm{C}$ to a constant weight. The residual and Petri dish weights were weighed after cooling in a desiccator to determine the cooking loss. The level of cooking loss was calculated by measuring the number of residual solids after drying. Percentage of rehydration and cooking loss was calculated by the following equation:

$$
\begin{aligned}
& \text { Rehydration }(\%)=\frac{\text { Weight of cooked analogs }- \text { Weight of uncooked analogs }}{\text { Weight of uncooked analogs }} \times 100 \\
& \text { Cooking loss }(\%)=\frac{\text { Weight of dried residues }}{\text { Weight of uncooked analogs }} \times 100
\end{aligned}
$$

The microstructure of analog rice was observed using TM 3000 Hitachi Scanning Electron Microscope (SEM) manufactured by Hitachi High-Technologies Corporation Tokyo Japan.

\section{Results and discussion}

\subsection{Physical characteristics}

The results of analog rice granules produced from different materials after extrusion were similar to rice, but the surface those analog grains were still rougher than milled rice, as detailed in Figure 1. The physical characteristics of analog rice in formulas $\mathrm{A}, \mathrm{B}, \mathrm{C}$, and milled rice are shown in Table 2. Table 2 shows the highest value of the weight of 100 grains obtained from milled rice of $3.3 \mathrm{~g}$, while the lowest in formula B was $2.9 \mathrm{~g}$. The highest bulk density values were obtained from milled rice at $0.55 \mathrm{~g} / \mathrm{mL}$, while the lowest bulk density values were obtained from Formula A, B and C. The highest WAI value was obtained from formula $\mathrm{B}$ at $217.5 \pm 3.22 \%$, while the lowest value was obtained from milled rice at $25.0 \pm 1.23 \%$.

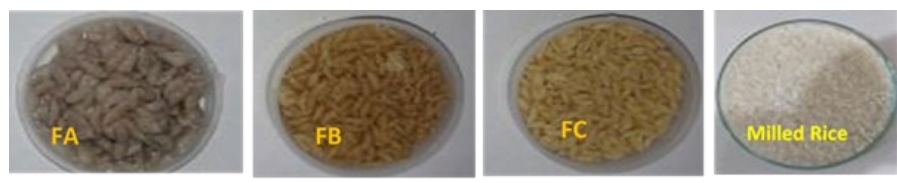

Figure 1. Analog rice granules from different materials after extrusion. FA: Ratio cassava : sorghum $:$ soybean $=4.5: 4.5$ : 1; FB: Ratio cassava : sweet potato $:$ soybean $=4.5: 4.5: 1$; FC: Ratio cassava : $50 \%$ corn $+50 \%$ lablab bean $:$ soybean $=$ $4.5: 4.5: 1 ; \mathrm{N}:$ Milled rice
Table 2. Weight of 100 analog rice grains, bulk density, and water absorption index in each formula treatment

\begin{tabular}{cccc}
\hline $\begin{array}{c}\text { The formula of } \\
\text { analog rice }\end{array}$ & $\begin{array}{c}\text { Weight of } 100 \\
\text { grains }(\mathrm{g})\end{array}$ & $\begin{array}{c}\text { Bulk Densities } \\
(\mathrm{g} / \mathrm{mL})\end{array}$ & WAI $(\%)$ \\
\hline A & 3.0 & 0.5 & $217.5 \pm 3.22$ \\
$\mathrm{~B}$ & 2.9 & 0.5 & $222.5 \pm 2.47$ \\
$\mathrm{C}$ & 3.3 & 0.51 & $118.0 \pm 2.05$ \\
$\mathrm{~N}$ & 3.3 & 0.55 & $25.0 \pm 1.23$ \\
\hline
\end{tabular}

A: Ratio cassava: sorghum : soybean $=4.5: 4.5: 1$; B: Ratio cassava : sweet potato : soybean= 4.5:4.5: 1; C: Ratio cassava : $(50 \%$ corn $+50 \%$ lablab bean $):$ soybean $=4.5:$ $4.5: 1 ; \mathrm{N}:$ Milled rice

The weight of 100 grains represented the weight of each type of analog rice so that it could be used to determine the weight of production. The data showed that the average weight per 100 grains of each type of analog rice was $(2.9 \mathrm{~g}-3.3 \mathrm{~g})$, which was lower than that of the milled rice $(3.3 \mathrm{~g})$. The weights found in every 100 grains of analog rice were influenced by structure, air cavity, and moisture content. The results of our observation, obtained with the help of Scanning Electron Microscope, showed that analog rice possessed more air cavities (Figure 3A and Figure 3B). The formula $\mathrm{C}$ of analog rice possessed the highest water content and it affected the 100 grains weight of this type.

Bulk density was the density of bulk material in a balanced volume. When granules or flour were being handled in large quantities, the bulk contents would be the same as the contents of solid objects plus the contents of the space (pores). Table 2 shows the bulk density of analog rice in formulae $\mathrm{A}, \mathrm{B}$, and $\mathrm{C}$. As for the bulk density of our analog rice, there was no difference. The bulk density of formula A, B, and C was $0.50-0.51 \mathrm{~g} /$ $\mathrm{mL}$. The bulk density and porosity of extruded products were dependent on feed moisture content, residence time, and temperature (Thymi et al., 2005; Gopirajah and Muthukumarappan, 2018). In this study, feed moisture content, residence time, and temperature were not varied. The amount of bulk density affected the broadness of the places needed by the materials. The higher the bulk density (particles), the smaller the place needed (Setiawati et al., 2014).

The data of analog rice's ability to absorb and retain water according to the formula of rice analog during the immersion process is shown in Figure 2.The WAIs of analog rice that was formulated from cassava, sorghum, and soybean, as well as the one formulated from cassava, sweet potato, and soybean, were higher. Those types of analog rice absorbed more water compared to the analog rice which was formulated from cassava, corn + lablab bean, and soybean. It was caused by the influence of the type of starch and its interaction with the protein from 
soy flour. Cassava, sorghum, and sweet potato possessed higher amylopectin content than corn. The value of WAI increased after 10 - 50 mins. The gelatinization of amylopectin would make the bonding process between hydrogen and water occurred more comfortably. That temperature was related to starch gelatinization (EstradaGirón et al., 2015). In the formula of corn + lablab bean flour, the water-absorbing process was slow because the corn and lablab bean starch contain higher amylose than sorghum and sweet potato. Furthermore, it was reported by (Estrada-Girón et al., 2015) that the composition of extruded corn starch, protein pinto, and navy beans creates a low WAI value.

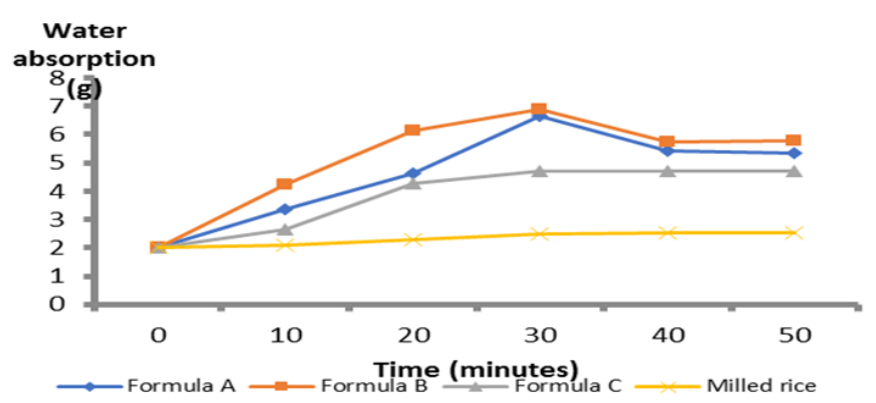

Figure 2. Water absorption index (WAI) of analog rice formula $\mathrm{A}, \mathrm{B}, \mathrm{C}$, and milled rice.

\subsection{Cooking properties}

The characteristic of analog rice was consisted of cooking time, cooking weight, degree of expansion, rehydration, and cooking loss in each treatment (Table $3)$. Table 3 shows the shortest cooking time obtained from Formula A for $9.0 \pm 1.0$ mins, while the longest cooking time was obtained from milled rice for $30.0 \pm 2.00$ mins. The highest cooking weight value was obtained from Formula $\mathrm{C}$ at $232.5 \pm 4.33 \%$, while the lowest was obtained from Formula B at $202.5 \pm 2.55 \%$. The highest Degree of expansion value was obtained from Formula $\mathrm{C}$ at $3.25 \pm 0.21$ and the lowest value obtained from Formula A was $2.50 \pm 0.13$. Milled rice has the highest rehydration value of $142.5 \pm 2.10 \%$, while the highest cooking loss value obtained from Formula B is $17.72 \pm 1.15 \%$.

Cooking time was the required time in cooking analog rice until a perfectly cooked analog rice could be obtained. The cooking time of analog rice for formula A,
$\mathrm{B}$, and $\mathrm{C}$ was between 8-13 mins (Table 3). This research used the cooking time similar to the cooking time of rice noodles, developed with extrusion technology between 5 to 9 mins (Yogeshwari et al., 2018). The cooking time of analog rice products was greatly influenced by the temperature of gelatinization that occurred in the used material. Higher gelatinization temperature would increase the value of analog rice cooking time. The temperature of starch gelatinization was highly dependent on the source of the constituent raw materials. Amylose affected the ability of starch to absorb water in a greater amount. Amylose had the greater ability to bond hydrogen with water when compared to the amylopectin.

Cooking weight. The analog rice cooking weight for formula $\mathrm{A}, \mathrm{B}$, and $\mathrm{C}$ was $202.5 \pm 2.55 \%$ to $232.5 \pm 4.33 \%$. It was lower than the cooking weight of milled rice $(242.5 \pm 4.00 \%)$. The highest cooking weight was possessed by analog rice in formula $\mathrm{C}$, which was $232.5 \pm 4.33 \%$. This condition was related to the amylose content within the extrudate. The amylose affected the starch's ability to absorb and retain water.

The degree of expansion illustrates the ability of analog rice to expand during cooking. Expansion during cooking using water with a ratio of 1: 1.5 (material: water) expansion has increased in all formulas where analog rice formula $\mathrm{C}$ has a degree of expansion 3.25 , and this value is higher than the expansion of milled rice (Table 3). The degree of expansion is related to the size, amount, and distribution of air surrounded by a cooked matrix (Yanniotis et al., 2007). Water is an excellent material as a plasticizer from the amorphous region of starch granules. Besides that, it also encourages the breaking of hydrogen bonds and the formation of new hydrogen fishes, among other related components. Expansion of extrudates will decrease if the amount of amylopectin in the material increases (Huang, 2001). The condition causes the analog rice that contains cornflour to possess a higher expansion when compared to the 'native rice' during the cooking process.

The percentage of rehydration of formula A, B, and $\mathrm{C}$ analog rice after the extruding process showed a hydration level of $102.5 \pm 3.64 \%$ to $132.5 \pm 4.33 \%$.

Table 3. Cooking time, cooking weight, degree of expansion, rehydration, and cooking loss in each formula

\begin{tabular}{cccccc}
\hline $\begin{array}{c}\text { The formula of } \\
\text { analog rice }\end{array}$ & $\begin{array}{c}\text { Cooking time } \\
(\mathrm{mins})\end{array}$ & $\begin{array}{c}\text { Cooking weight } \\
(\%)\end{array}$ & $\begin{array}{c}\text { Degree of } \\
\text { Expansion }\end{array}$ & Rehydration (\%) & Cooking loss (\%) \\
\hline A & $9.0 \pm 1.0$ & $207.5 \pm 3.20$ & $2.50 \pm 0.13$ & $107.5 \pm 3.70$ & $16.08 \pm 1.10$ \\
B & $7.0 \pm 1.0$ & $202.5 \pm 2.55$ & $2.25 \pm 0.22$ & $102.5 \pm 3.64$ & $17.72 \pm 1.15$ \\
C & $11.0 \pm 0.66$ & $232.5 \pm 4.33$ & $3.25 \pm 0.21$ & $132.5 \pm 4.33$ & $12.08 \pm 1.03$ \\
N & $30.0 \pm 2.00$ & $242.5 \pm 4.00$ & $3.20 \pm 0.22$ & $142.5 \pm 2.10$ & $6.00 \pm 0.60$ \\
\hline
\end{tabular}

A: Ratio cassava: sorghum : soybean $=4.5: 4.5: 1$; B: Ratio cassava : sweet potato : soybean= 4.5:4.5: 1 ; $:$ Ratio cassava : $(50 \%$ corn $+50 \%$ lablab bean $):$ soybean $=4.5: 4.5: 1 ; \mathrm{N}:$ Milled rice 
Rehydration level of analog rice was highest in formula $\mathrm{C}$ but still lower than the rehydration level of milled rice, which was $142.5 \pm 2.10 \%$. These conditions were related to the extrudate conditions, weight per seed, and the ability to absorb and retain water.

The level of cooking loss of formula A, B, and C analog rice was $12.08-17.72 \%$. This result was still higher than that of the milled rice $(6 \%)$. Significant cooking loss was undesirable because starch solubility occurs when this type of rice is being cooked. This condition would produce boiled water that is turbid or analog rice which is low in cooking tolerance and sticky to the mouth (Yogeshwari et al., 2018). The lowest cooking loss value was possessed by formula $\mathrm{C}$ analog rice $(12.08 \pm 0.03 \%)$. These results indicated that the number of solids in formula $\mathrm{C}$ was less soluble in water during the cooking. The difference in starch sources might affect the cooking loss of noodles (Quazi et al., 2014).

\subsection{Nutrient analysis}

The proximate composition of the analog rice of formula A, B, C, and milled rice are shown in Table 4. Table 4 shows that Formula $\mathrm{C}$ has a higher protein content of $13.08 \mathrm{~g} / 100 \mathrm{~g}$ when compared to Formula A protein of $10.39 \mathrm{~g} / 100 \mathrm{~g}$ and Formula $\mathrm{B}$ of $6.71 \mathrm{~g} / 100 \mathrm{~g}$. Formula $\mathrm{C}$ also has the highest value in Fat at $5.87 \mathrm{~g} / 100$ $\mathrm{g}$, crude fiber at $9.51 \mathrm{~g} / 100 \mathrm{~g}$, amylose at $36.05 \mathrm{~g} / 100 \mathrm{~g}$, and ash at $1.66 \mathrm{~g} / 100 \mathrm{~g}$ when compared to Formula A and $\mathrm{B}$. Formula $\mathrm{C}$ has the lowest value at starch, $\mathrm{Ca}$ and $\mathrm{P}$ when compared to Formula $\mathrm{A}$ and $\mathrm{B}$, the starch value of $64.05 \mathrm{~g} / 100 \mathrm{~g}$, Ca of $24 \mathrm{mg} / 100 \mathrm{~g}$ and $\mathrm{P}$ of $79 \mathrm{mg} / 100$ g.

The average moisture content of analog rice of formula $\mathrm{A}, \mathrm{B}$, and $\mathrm{C}$, whose component ingredients consist of various main ingredients such as wood flour, sorghum flour, cornflour, and sweet potato flour was 9.87-12.05 g/100 g (Table 4). The obtained water content had reached the level of ground rice water, which was around $11.62 \mathrm{~g} / 100 \mathrm{~g}$. The maximum moisture content of ground rice (14\%) is required by SNI 01-6128-2008 (Pudjihastuti et al., 2019). The level of water content in analog rice after extrusion was influenced by material formula, extrusion temperature, and the drying process performed after the extrusion process.

The average crude protein content from the analog rice of formula $\mathrm{A}, \mathrm{B}$, and $\mathrm{C}$ was $6.71 \mathrm{~g} / 100 \mathrm{~g}-13.08$ $\mathrm{g} / 100 \mathrm{~g}$ (Table 4). These results indicated that the protein content of analog rice was higher than that of the milled rice, which was $6.81 \mathrm{~g} / 100 \mathrm{~g}$ (USDA, 2015). The amount of protein within the formula $\mathrm{A}, \mathrm{B}$, and $\mathrm{C}$ was determined by the addition of protein from soy flour (the protein content in soy flour is more than $38.00 \%$ ). The lowest protein content went to the analog rice of formula B. This condition occurred because the protein content of this analog rice was directly proportional to the protein content of the used base material. Protein contents in formula $\mathrm{A}$ and formula $\mathrm{C}$ were higher than that of the formula B. This was due to the influence of soy protein, corn+lablab bean protein, and sorghum, in which the amount of those contents was higher than that of the sweet potato protein. The protein content of the produce analog rice is highly dependent on the raw materials (Akdogan, 1999; Noviasari et al., 2017). The presence of protein in analog rice formulae can also be functioned to reduce the glycemic response because protein can prolong the rate of food flow in the stomach so that the absorption and digestion speed in the small intestine becomes slower (Alsaffar, 2011). These conditions would indirectly be the benefit of analog rice as a functional food.

Table 4. The proximate composition of the analog rice formula A, B, C, and milled rice

\begin{tabular}{|c|c|c|c|c|c|}
\hline No & Component & 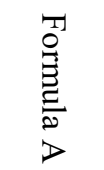 & 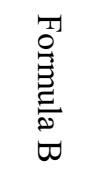 & 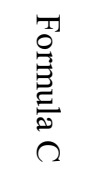 & $\begin{array}{l}3 \\
\frac{3}{8} \\
\frac{2}{2} \\
\frac{1}{8}\end{array}$ \\
\hline 1 & Water $(\mathrm{g} / 100 \mathrm{~g})$ & 9.87 & 11.9 & 12.05 & 11.62 \\
\hline 2 & Protein $(\mathrm{g} / 100 \mathrm{~g})$ & 10.39 & 6.71 & 13.08 & 7.13 \\
\hline 3 & Fat $(\mathrm{g} / 100 \mathrm{~g})$ & 4.87 & 4.66 & 5.87 & 0.66 \\
\hline 4 & Crude fiber $(\mathrm{g} / 100 \mathrm{~g})$ & 7.92 & 7.71 & 9.51 & 0.12 \\
\hline 5 & $\operatorname{Starch}(g / 100 g)$ & 76.4 & 80.55 & 64.05 & 90 \\
\hline 6 & Amylose (g/100 g) & 34 & 19.93 & 36.05 & 17 \\
\hline 7 & $\operatorname{Ash}(g / 100 g)$ & 0.72 & 0.55 & 1.66 & 0.8 \\
\hline 8 & $\mathrm{Ca}(\mathrm{mg} / 100 \mathrm{~g})$ & 92 & 30 & 24 & 28 \\
\hline 9 & $P(\mathrm{mg} / 100 \mathrm{~g})$ & 188 & 80 & 79 & 115 \\
\hline
\end{tabular}

The average fat content in the analog rice of formula $\mathrm{A}, \mathrm{B}$, and $\mathrm{C}$ was $4.66-5.87 \mathrm{~g} / 100 \mathrm{~g}$ (Table 4). This fat content level was higher than the fat content of the milled rice, which was $0.55 \mathrm{~g} / 100 \mathrm{~g}$ (USDA, 2015). The fat content was higher in the analog rice due to the addition of oil in the dough before extrusion. The oil is essential to avoid adhesions during extrusion and to produce analog rice whose surface is finer. Fat can reduce the frictional force between particles and between the surface of the screw and barrel (Assoud and Kleinke, 2005). These conditions can improve the smoothness of analog rice's surface.

The data provided in Table 3 show that the amylose content of analog rice (formula A, B, and C) was between 34.0 - 36.05\%, while the milled rice contained amylose in the amount of $17 \mathrm{~g} / 100 \mathrm{~g}$. Amylose and amylopectin affect the texture of rice and analog rice after cooking (Budijanto and Yuliyanti, 2017). The high 
amylose will produce dry analog rice that has a hard texture after being cold. Rice containing high amylopectin will produce fluffier rice with as of texture (Yusof et al., 2005). The amylose content of the raw materials would be related to the level of consumer acceptance and it could bring influence on the cooking process (Wang et al., 2010). However, in the production process, Na-alginate and soy flour were added to the formula in a fixed amount, and it affected the texture of analog rice after being cooked.

The data in Table 3 show that the fiber content of the analog rice (formula $\mathrm{A}, \mathrm{B}$, and $\mathrm{C}$ ) was relatively high (at $7.71-9.51 \%$ ), while the fiber content of the milled rice was about $0.12 \mathrm{~g} / 100 \mathrm{~g}$. The relatively high fiber content in analog rice was because the fiber content of the base material used in creating analog rice was relatively high. According to the Codex Alimentarius Commission (2009), food would be deemed as a source of dietary fiber if it contains at least $3 \%$ of fiber, and it would be considered 'high in fiber' if it contains at least $6 \%$ of dietary fiber (Howlett et al., 2010).

\subsection{Microstructure}

The structure of the analog rice after the extruding process will be shown in (Figure 3A), and the gel structure after cooking will be shown in (Figure 3B). The microstructures of the analog rice (formulas $\mathrm{A}, \mathrm{B}$, and $\mathrm{C}$ ) differed from the structure of the milled rice. Starch and protein components were gelatinized during the heating that occurred in the extruder machine. Furthermore, the components also gained an interaction with each other to form a compact structure, but there were still cavities on the analog rice's surface when compared to the real rice (Figure 3A). Heating and compression during the extrusion process can cause the gelatinization process either partially or entirely (Mishra et al., 2012). The structure of post-extruded analog rice was influenced by feed moisture in the formula of the extrudates. The water would serve as a plasticizer agent for starch material and it can reduce viscosity and mechanical energy, as well as inhibit the growth of bubbles, resulting in a denser product (Assoud and Kleinke, 2005). Post-cooking microstructure gel development occurred due to the presence of water and the heating. The gel developed in each formula was different from the gel in the milled rice. The difference in the shape of the gels was due to the variations in the ingredients of its constituent formulas. In analog rice made of various sources of starch and protein (sorghum, cassava, corn, cassava, and soybeans), the form of starch granules in each ingredient was different so the gelatinization process also formed a different gel. In addition, it was suspected that, by the process of mixing and extruding at high temperatures, accompanied by complaints and high pressure, there was an interaction between the components.
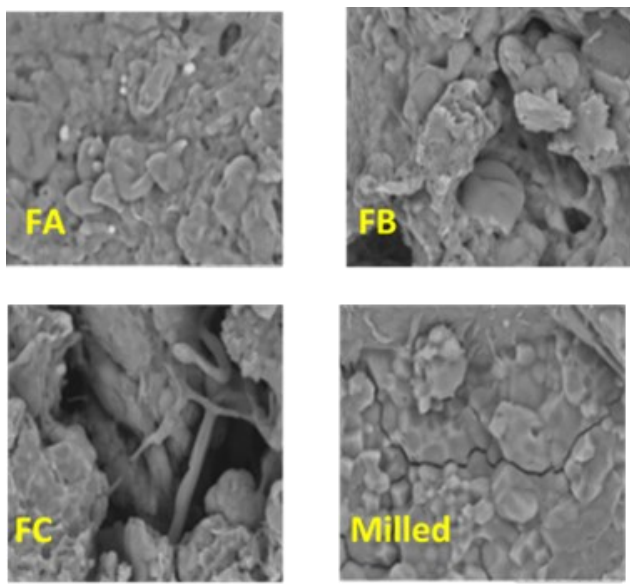

Figure 3A. Scanning electron microscopy of analog rice granules uncooked
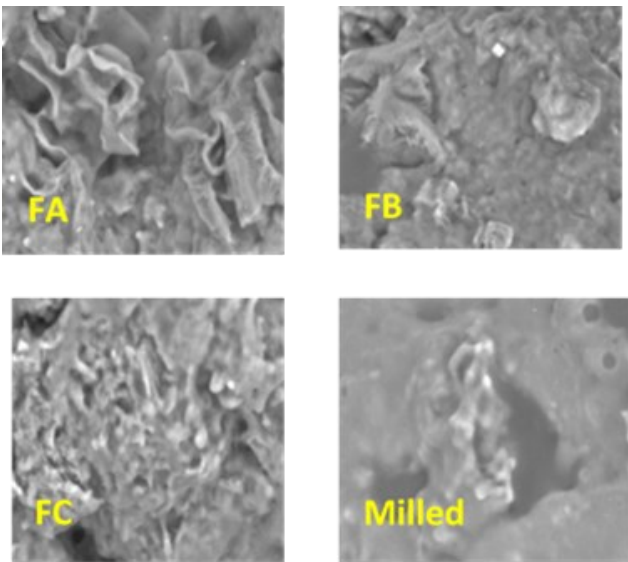

Figure 3B. Scanning electron microscopy of analog rice granules cooked

\subsection{Sensory of analog rice}

The results of the color sensory test performed by using ten panelists showed that the color value of analog rice in formulas $\mathrm{A}, \mathrm{B}$, and $\mathrm{C}$ was 5 to 7 (i.e., preferred to highly preferred). When we take a deep look, the white color was still below the milled rice. Based on the panelist's evaluation on the formula $\mathrm{B}$, it showed a highly preferred color with a score of 5.8, but still lower than the color score of the milled rice. Formula A and B showed a score of 4.4 to 5.1, which meant preferable. The difference in color between analogous rice and milled rice was due to the non-rice ingredients (within the analog rice) whose initial color was not white, unlike the milled rice.

The results of the texture test using ten panelists showed that the analog rice (formulas A, B, and C) possessed a score of 4 to 5 , which means somewhat preferable to preferable. The highest texture score was found in formula $\mathrm{B}$ with a value of 5. Formula $\mathrm{B}$ contained lower amylose.

The taste test results showed that the analog rice of formulas $\mathrm{A}, \mathrm{B}$, and $\mathrm{C}$ had a taste value of 4 to 5, which 
mean preferable, but when compared to the milled rice, it still got a lower score. The most preferable flavor went to formula $\mathrm{C}$, which possessed a value of 5 .

The aroma test results indicated that the numbers of 4 to $5 \mathrm{~m}$ which meant 'preferable', but when compared to the aroma of rice from ordinary milled rice, it still got a lower score. The essential ingredients influence the texture, taste, and aroma of the analog rice (formulas A, $\mathrm{B}$, and $\mathrm{C}$ ). Moreover, the panelists were accustomed to consuming the milled rice. This condition was thought to have caused the lower score of sensory tests for the analog rice when compared to that of the milled rice.

\section{Conclusion}

Flours from: cassava, sweet potato, sorghum, corn, and soybeans can be formulated as an analog rice ingredient. Cassava flour, sweet potato, sorghum, corn, lablab bean act as a source of carbohydrates, and soy flour is used as a source of protein. The best ratio will be 4.5: 4.5 : 1 for the cassava flour: $(50 \%$ corn $+50 \%$ lablab bean) flour: soy flour. This formula uses a number of additional ingredients such as $250 \mathrm{~g}$ cooking oil, $50 \mathrm{~g}$ salt, glycerol monostearate (GMS) $25 \mathrm{~g}, 25 \mathrm{~g} \mathrm{Na}$. alginate and $25 \mathrm{~g}$ sodium three polyphosphates (STPP) per $10 \mathrm{~kg}$ of dough. The average nutritional composition is higher than that of milled rice, especially protein $=$ $13.08 \%$, fat $=5.87 \%$, fiber $=9.51 \%$, and amylose $=$ $36.05 \%$. The amount of water used in the cooking process must be $1.5 \mathrm{~mL}$ to $2 \mathrm{~mL}$ per gram of analog rice, and the cooking time must be 10-15 mins. The sensory value of color, taste, aroma, and texture of the analog rice is in the scale of average like to very like, even though it is still lower than that of the milled rice.

\section{Conflict of interest}

The authors declare no conflict of interest.

\section{Acknowledgments}

Thanks to the Directorate of Research and Community Service, Directorate General of Research and Development Ministry of Research and the Higher Education Republic of Indonesia, which has provided financial assistance through national research programs.

\section{References}

Adicandra, R.M. and Estiasih, T. (2016). Beras Analog dari ubi kelapa putih. Pangan dan Agroindustri. 4 (1), 383-390.

Akdogan, H. (1999). High moisture food extrusion. International Journal of Food Science and Technology, 34(3), 195-207. https://doi.org/10.1046/ j.1365-2621.1999.00256.x

Alsaffar, A.A. (2011). Effect of food processing on the resistant starch content of cereals and cereal products - a review. International Journal of Food Science and Technology, 46(2), 455-462. https:// doi.org/10.1111/j.1365-2621.2010.02529.x

AOAC. (1995). Official methods of analysis of AOAC International, Association of Official Analysis Chemists International. USA: AOAC.

Assoud, A. and Kleinke, H. (2005). Unique barium selenostannate-selenide: $\mathrm{Ba}_{7} \mathrm{Sn}_{3} \mathrm{Se}_{13}$ (and its variants $\mathrm{Ba}_{7} \mathrm{Sn}_{3} \mathrm{Se}_{13}-\delta \mathrm{Te} \delta$ ) with $\mathrm{SnSe}_{4}$ tetrahedra and isolated Se anions. Chemistry of Materials, 17(17), 45094513. https://doi.org/10.1021/cm050787y

Budijanto, S. and Yuliyanti (2017). Studi persiapan tepung sorgum dan aplikasinya pada pembuatan beras analog (Study of preparation sorghum flour). Jurnal Teknologi Pertanian, 13, 177-186.

Caesarina, I. and Estiasih, T. (2016). Beras analog dari garut ( Maranta arundinaceae). A Review. Jurnal Pangan dan Agroindustri, 4, 498-504. [In Bahasa Indonesia].

Estrada-Girón, Y., Martínez-Preciado, A.H., Michel, C.R. and Soltero, J.F.A. (2015). Characterization of extruded blends of corn and beans (Phaseolus Vulgaris) cultivars: Peruano and black-querétaro under different extrusion conditions.International Journal of Food Properties, 18(12), 2638-2651. https://doi.org/10.1080/10942912.2014.999862

Fang, Y., Ji, J., Zhang, J., Liu, S., Liu, J. and Ding, Y. (2019). Effect of extrusion cooking on physicochemical properties of tuna meat-based extrudates. Food Science and Technology, 39(3), 627 -634. https://doi.org/10.1590/fst.36617

Fari, M.J.M., Rajapaksa, D. and Ranaweera, K.K.D.S. (2011). Quality characteristics of noodles made from selected varieties of Sri Lankan rice with different physicochemical characteristics. Journal of the National Science Foundation of Sri Lanka, 39(1), 53 -60. https://doi.org/10.4038/jnsfsr.v39i1.2923

Fukase, E. and Martin, W. (2017). Economic growth, convergence, and world food demand and supply. Policy Research Working Paper 9257. USA: Agriculture and Rural Development Team. https:// doi.org/10.1596/1813-9450-8257

Gandhi, V.P. and Zhou, Z. (2014). Food demand and the food security challenge with rapid economic growth in the emerging economies of India and China. Food Research International, 63(Part A), 108-124. https:// doi.org/10.1016/j.foodres.2014.03.015

Gopirajah, R. and Muthukumarappan, K. (2018). Effect of extrusion process conditions on the physical 
properties of tef-oat healthy snack extrudates. Journal of Food Processing and Preservation, 42(3). https://doi.org/10.1111/jfpp.13559

Hasnelly, M.E.S. and Putri, P.S. (2013). Kajian proses pembuatan dan karakteristik beras analog ubi jalar (Ipomoea batatas) presented at the Seminar Rekayasa Kimia dan Proses, 2013, p. 1-8. Indonesia: Fakultas Teknik Universitas Pasundan. [In Bahasa Indonesia].

Howlett, J., Betteridge, V., Champ, M., Craig, S.S., Meheust, A. and Jones, J.M. (2010). The definition of dietary fiber-discussions at the Ninth Vahouny Fiber Symposium: building scientific agreement. Food and Nutrition Research, 54(1), 5750. https:// doi.org/10.3402/fnr.v54i0.5750

Huang, D.P. (2001). Selecting an optimum starch for snack development. Cereal Foods World, 46(6), 237 -239 .

Katsavou, I.D., Tsikopoulos, K.C.T., Eleni, P.N. and Krokida, M.K.(2019) 'Sensorial, functional, optical and thermal properties of inulin enriched expanded products. International Food Research Journal, 26 (2), 687-671.

Mishra, A., Mishra, H.N. and Rao, P.S. (2012). Preparation of rice analogues using extrusion technology. International Journal of Food Science and Technology, 47, 1789-1797. https:// doi.org/10.1111/j.1365-2621.2012.03035.x

Mulyani, A., Kuntjoro, D., Nursyamsi, D. and Agus, F. (2016). Konversi lahan sawah Indonesia sebagai ancaman terhadap ketahanan pangan. Jurnal Tanah dan Iklim, 40(2), 121-133. [In Bahasa Indonesia]. https://doi.org/10.2017/jti.v40i2.5708.

Noviasari, S., Kusnandar, F. and Budijanto, S. (2013). Pengembangan beras analog dengan memanfaatkan jagung putih. Jurnal Teknologi dan Industri Pangan, 24(2), 194-200. [In Bahasa Indonesia]. https:// doi.org/10.6066/jtip.2013.24.2.194

Noviasari, S., Widara, S.S. and Budijanto, S. (2017). Analogue rice as the vehicle of public nutrition diversity. Jurnal Kesehatan Masyarakat, 13(1), 1827. https://doi.org/10.15294/kemas.v13i1.8284

Pudjihastuti, I., Sumardiono, S., Supriyo, E. and Kusumayanti, H. (2019). Analog rice characteristics made from sago flour and arrowroot flour in supporting food diversification. AIP Conference Proceedings, 2114, $030004 . \quad \mathrm{https} / /$ doi.org/10.1063/1.5112408

Qazi, I., Rakshit, S.K., Tran, T., Ullah, J. and Khan, M.Z. (2014). Effect of blending selected tropical starches with rice flour on the cooking quality and texture of rice based noodles. Sarhad Journal of
Agriculture, 30(2). 257-264.

Setiawati, N.P., Santoso, J. and Purwaningsih, S. (2014). Karakteristik beras tiruan dengan penambahan rumput laut eucheuma cottonii sebagai sumber serat pangan. Jurnal Ilmu dan Teknologi Kelautan Tropis, 6(1), 197-208. [In Bahasa Indonesia]. https:// doi.org/10.28930/jitkt.v6i1.8641

Sukamto, S. (2018). Produksi dan pengembangan beras analog sebagai bahan makanan pokok nasional masa depan, presented at Conference on Innovation and Application of Science and Technology (CIASTECH), p. 1-9. Indonesia: Universitas Widyagama Malang. [In Bahasa Indonesia].

Sukamto, S., Sui, M., Sudiyono,Domas, G.P. and Karim, F. (2019). Pojale (ketela pohon jagung dan kedelai) sebagai bahan pengembangan beras analog pengendali kegemukan). Jurnal Lahan Suboptimal, 7 (2), 128-125. [In Bahasa Indonesia]. https:// doi.org/10.33230/JLSO.7.2.2018.353

Thymi, S., Krokida, M.K., Pappa, A. and Maroulis, Z.B. (2005). Structural properties of extruded corn starch. Journal of Food Engineering, 68(4), 519-526. https://doi.org/10.1016/j.jfoodeng.2004.07.002

USDA. (2015). National Nutrient Database for Standard Reference. Retrieved from USDA Website: https:// data.nal.usda.gov/dataset/usda-national-nutrientdatabase-standard-reference-legacy-release

Wang, X.Q., Yin, L.Q., Shen, G.Z., Li, X. and Liu, Q.Q. (2010). Determination of amylose content and its relationship with RVA profile within genetically similar cultivars of rice (Oryza sativa L. ssp. japonica). Agricultural Sciences in China, 9(8), 1101 -1107. https://doi.org/10.1016/S1671-2927(09)60196 $-6$

Yanniotis, S., Petraki, A. and Soumpasi, E. (2007). Effect of pectin and wheat fibers on quality attributes of extruded cornstarch. Journal of Food Engineering, 80(2), 594-599. https:// doi.org/10.1016/j.jfoodeng.2006.06.018

Yogeshwari, R., Hemalatha, G., Vanniarajan, C., Saravanakumar, R. and Kavithapushpam, A. (2019). Development of Micronutrient Fortified Extruded Rice Analogues. European Journal of Nutrition and Food Safety, 9(1), 1-11. https://doi.org/10.9734/ EJNFS/2019/44342

Yusof, B.N.M., Talib, R.A. and Karim, N.A. (2005). Glycaemic index of eight types of commercial rice in Malaysia, Malaysian Journal of Nutrition, 11(2), 151 $-163$. 